\title{
Experimental model of obtaining tissue adipose, mesenchymal stem cells isolation and distribution in surgery flaps in rats $^{1}$
}

\author{
André Luiz Pires de Freitas ${ }^{\mathrm{I}}$, Marcelo de Oliveira e Silva ${ }^{\mathrm{I}}$, Priscilla Martin Keiko Matsumoto ${ }^{\mathrm{II}}$, Sang Won Han ${ }^{\mathrm{III}}$, Lydia Masako \\ Ferreira $^{\text {IV }}$ \\ DOI: http://dx.doi.org/10.1590/S0102-86502014001400006 \\ IPostgraduate student, Program in Translational Surgery, Federal University of Sao Paulo (UNIFESP), Brazil. \\ IIMaster, Interdisciplinary Center for Gene Therapy (CINTERGEN), UNIFESP, Sao Paulo-SP, Brazil. \\ IIIProfessor, Interdisciplinary Center for Gene Therapy (CINTERGEN), UNIFESP, Sao Paulo-SP, Brazil.

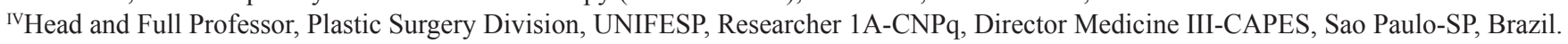

\begin{abstract}
PURPOSE: To investigate the experimental model for obtaining adipose tissue, isolation, characterization of mesenchymal stem cells and evaluation of their distribution in the tram flap in rats.

METHODS: Five rats of Wistar were randomly assigned to two groups. In group I, three animals underwent removal of adipose tissue in the groin procedure to establish the experimental model and obtain a cell lineage. The animals of group II $(n=2)$ underwent surgical flap procedure, and satisfaction injection of mesenchymal stem cells pretreated with marker fluorescente.

RESULTS: obtaining adipose tissue of the inguinal region of the rat proved to be possible. The isolated cells were characterized as mesenchymal stem cells and fluorescence microscopy showed the presence of multiple cells arranged around blood vessels and capillaries.
\end{abstract}

CONCLUSION: It was possible to establish an experimental model for obtaining adipose tissue for isolation of mesenchymal stem cells and their distribution in the TRAM flap in rats.

Key words: Stem Cells, Adipose Tissue, Animal Models, Mesenchymal Stem Cell Transplantation, Surgical Flaps. 


\section{Introduction}

Many studies with adult stem cells have been focused on mesenchymal stem cells derived from bone marrow. Adipose tissue such as the bone marrow-derived embryonic mesenchyme and contains a stroma easily isolated ${ }^{1-3}$. Preliminary studies have identified stem cells in the stromal compartment of adipose tissue. This population of cells can differentiate into osteogenic lineage, chondrogenic, myogenic and chondrogenic ${ }^{1-3}$. Stem cells are cells with the ability to differentiate into various cell types, including endothelial progenitor cells ${ }^{4}$. The stem cells derived from adipose tissue can differentiate into osteogenic lineage, chondrogenic, adipogenic, myogenic, neurogenic and angiogenic ${ }^{1-3,5-8}$. Previous studies identified the presence of mesenchymal stem cells in adipose tissue, which can be isolated similarly to the cells derived from bone marrow. The use of this cell mode has major advantages, the ease in obtaining it, removal of large number of cells and a lower morbidity of the donor area ${ }^{9}$

The lack of studies in the literature describing the experimental model for obtaining adipose tissue in rats and especially the protocol of differentiation and immunophenotyping of mesenchymal stem cells derived from adipose tissue, marking and tracing, spurred the development of this study.

\section{Methods}

This study was submitted to the UNIFESP Research Ethics Committee (0148/12).

Five Wistar rats, adult male, weighing between 250 and 300 grams (g) aged three months were obtained from the Central Animal Laboratory of the Federal University of São Paulo (UNIFESP) were used. The animals were randomized into two groups. In group I, three animals underwent removal of adipose tissue in the groin procedure to establish the experimental and obtain a cell line model. The animals of group II $(n=2)$ underwent TRAM flap procedure, and solution injection of mesenchymal stem cells pretreated with CM-DiI fluorescent marker (Life Technologies) solution.

\section{Food, anesthesia and animal preparation for procedures}

Anesthesia was induced with intraperitoneal application of tiletamine hydrochloride and zolazepam hydrochloride at a dose of $25 \mathrm{mg} / \mathrm{kg}$. Following anesthesia, the animals were immobilized in a dorsal decubitus position on a surgical board and the abdomen was shaved with an electric razor 76274 Oster (Oster, Tennessee, USA).

\section{Obtaining adipose tissue}

The adipose tissue was removed from the bilateral inguinal region of the rat. A line of three inches long was demarcated in the inguinal fold of the animal, with superior extension in the anterior axilar line measuring two centimeters and three centimeters distally from the midline. Asepsis and antisepsis of the area and placement of sterile drapes was performed. The incision was made with a scalpel blade 15 and the detachment of the flap with scissors. The resection of adipose tissue of the inguinal region fragment was made with scissors without the need for hemostasis. The removed fragment of each inguinal region was then referred for weighing (Figure 1).

After removal, the entire fragment of adipose tissue was placed into a sterile container containing fetal bovine serum (FBS).
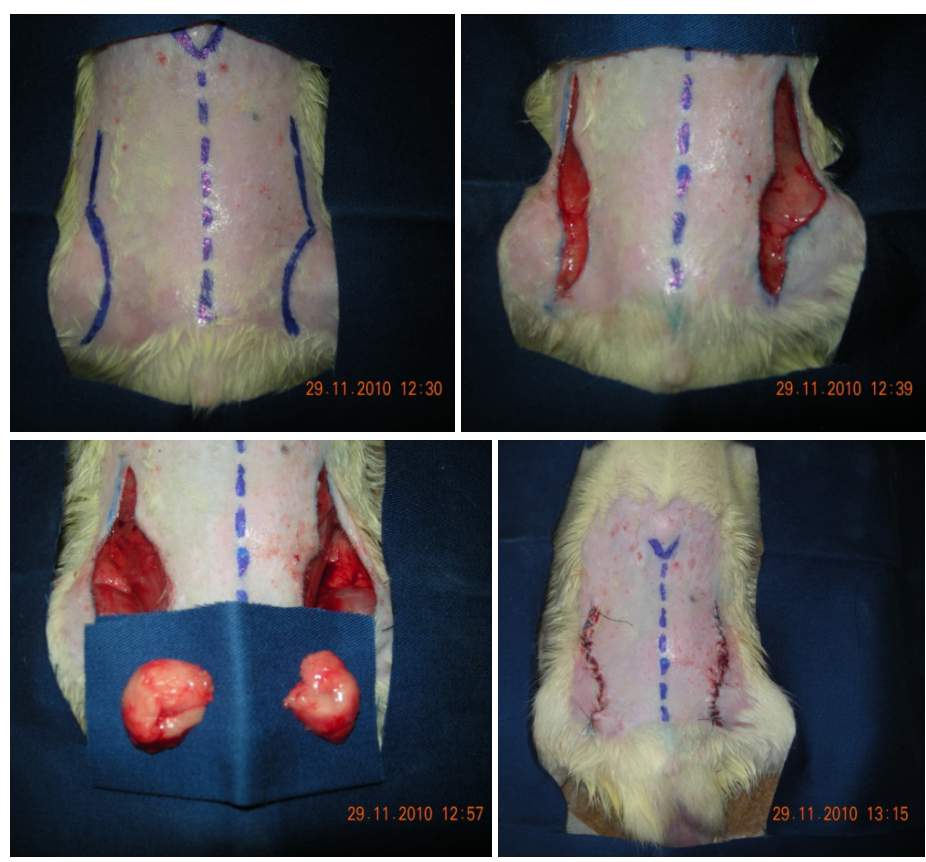

FIGURE 1 - Demarcation of the incision in the groin incision, removal of fat and suture the donor area.

\section{Preparation and isolation of stem cells}

After removing the tissue flap was shredded into small pieces and incubated in collagenase type I $1 \mathrm{mg} / \mathrm{ml}$ for 3 hours at 37 ${ }^{\circ} \mathrm{C}$ under stirring. Then the tube was centrifuged for 10 minutes at $800 \mathrm{xg}$ and the supernatant discarded. The cells were resuspended in aMEM medium (Gibco) (San Diego, CA, USA) supplemented with 200 mM L-glutamine (Gibco), 10,000 units / ml penicillin (Gibco), 10,000 units / $\mathrm{ml}$ streptomycin (Gibco) and 10\% fetal bovine serum (FBS) (Gibco), and subjected to counting in a Neubauer chamber. 
After counting the cells with trypan blue, the cells were incubated at a concentration of 2 X 106 cells / $\mathrm{ml}$ and maintained at $37^{\circ} \mathrm{C}$ in $5 \%$ carbon dioxide. Adherent cells were maintained in culture medium supplemented $\alpha \mathrm{MEM}$, at $37^{\circ} \mathrm{C}$ in a humidified $5 \% \mathrm{CO} 2$-containing atmosphere.

Only cultures with isolated stem cells from the third passage were used in the in vivo study. The cells were resuspended in $\alpha$ MEM medium at a concentration of $5 \times 105$ cells in $0.1 \mathrm{ml}$ for each injection point of the flap totaling $0.4 \mathrm{ml}$ or $2 \times 106$ cells per animal.

Cells were treated with fluorescent marker (1,1-Dioctadecyl-3 3.3-0.3-Tetramethylindocarbocyanine - IBD), to the study of its location in the retail and distribution by fluorescence microscopy.

\section{Characterization of stem cells derived from adipose tissue}

The third passage cells were analyzed by immunocytochemistry with primary antibodies CD105, CD73, CD90 and CD45 (Santa Cruz). All reactions were revealed with anti-mouse secondary antibody produced in rabbit and streptavidin conjugated to fluorochrome DS-RED 594.

The cells were also assessed for their proliferation as adherent cells and ability to differentiate in vitro into osteoblasts, adipocytes and chondroblasts ${ }^{10}$.

For osteogenic differentiation, the cells were grown at high confluence for approximately one month in $\alpha$ MEM medium containing 10\% FBS (Gibco), 10-8 M dexamethasone (Sigma), 5 $\mathrm{mg} / \mathrm{mL}$ ascorbic acid (Sigma) and $10 \mathrm{mM}$ of $\beta$-glycerophosphate (Sigma). For observation of the deposit of calcium, cells were fixed in 4\% paraformaldehyde for 30 minutes, washed with PBS and stained with Alizarin Red pH 4.2 (Sigma). Excess dye was removed with distilled water.

For adipogenic differentiation, the cells were cultured in aMEM medium containing 10-10 M dexamethasone (Sigma), 2.5 $\mathrm{mg} / \mathrm{mL}$ insulin (Sigma), $5 \mathrm{mM}$ rosiglitazone (Sigma). One month later, the cells were fixed in 4\% paraformaldehyde for 30 minutes, washed with PBS and stained with Oil Red (Sigma). Excess dye was removed with distilled water.

For chondrogenic differentiation, cells were cultured in $\alpha$ MEM $6.25 \mathrm{~g} / \mathrm{ml}$ insulin, $10 \mathrm{ng} / \mathrm{ml}$ TGF $\beta 1,50 \mathrm{nM}$ ascorbic acid and $10 \%$ FBS. One month later, the cells were fixed in $4 \%$ paraformaldehyde for 30 minutes, washed with PBS and stained with 2.5\% Alcian Blue (Sigma). Excess dye was removed with distilled water.

\section{Musculofasciocutâneo transversus abdominal rectus abdominal flap ${ }^{11-15}$}

The flap was demarcated in the cranial ventral region, measuring five centimeters in the transverse direction, taking the middle line as a parameter and three centimeters in the longitudinal direction, lying an inch from xiphoideus processus (xiphoid process).

The skin incision was made with a scalpel blade 15 in its entire extension, following the previous demarcation.

The detachment was made with scissors in suprafascial plan. The contralateral segment was displaced to the midline and the ipsilateral segment was taken off the right edge of the flap to the right edge of the rectus muscle of the right abdomen.

Flap was released with the midline incision and separation of the rectus muscles, the cranial portion of the rectus muscle of the right abdomen in the same line of skin incision incision incision along the right margin of the rectus muscle of the right abdomen. Flap was displaced caudally and stayed vascularized only by the caudal pedicle rectus right abdomen.

Silicone blade five inches wide, three inches long and three millimeters thick, was placed between the flap and the donor area ${ }^{13-16}$. Synthesis of the abdominal wall was performed with a continuous suture of 5-0 monofilament nylon and retail was distributed and secured with simple points of the same wire in the four corners and middle cranial point. The skin was sutured continuously, also with 5-0 monofilament nylon. Cervical collar made of plastic material is placed to avoid injury autophagy ${ }^{17}$. The collar was fastened with four-point nylon 0 , left lateral positions in the cranial, caudal, and right side. The animals were relocated in individual cages with food and water ad libitum.

\section{Application of mesenchymal stem cells}

During the TRAM flap procedure the solution containing mesenchymal stem cells was applied. $0.1 \mathrm{ml}$ of DMEM (phosphate buffered saline solution) solution containing five hundred thousand cells intradermally at each point of application, a single dose was applied totaling two million cells per animal. A 26 gauge needle was used to administer the solution in four points corresponding to each central zone of the TRAM flap areas. The area I call comprises the segment of skin between the midline and the lateral border of the rectus muscle of the right abdomen (pedicle). Zone II comprises the segment between the lateral border of the rectus muscle of the left abdomen and the midline. Zone III comprises the segment between the lateral border of the rectus muscle of the right abdomen and right lateral margin of the flap, and zone IV the 
segment between the lateral border of the rectus muscle of the left abdomen and the left edge of the flap (Figure 2$)^{18}$.

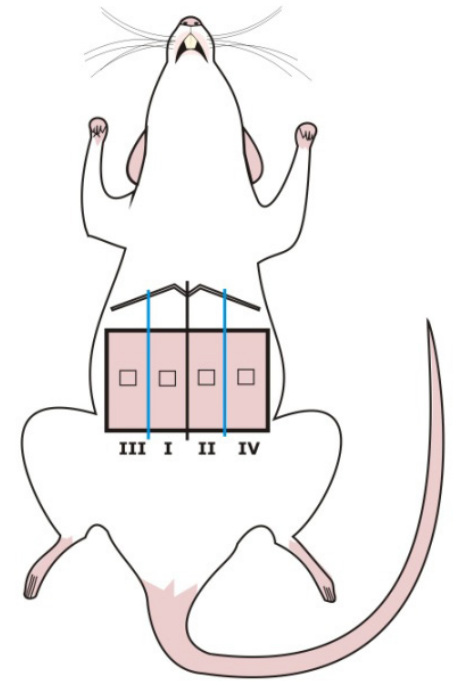

FIGURE 2 - Application points of the solution in the abdomen during the procedure of the TRAM flap.

\section{Distribution and origin of stem cells}

Fragment six millimeters, which was withdrawn from the center of each zone of the TRAM flap ${ }^{19}$, corresponding to the point of application. Photographs were taken on a fluorescence microscope. Initially a panoramic lens examination under a $100 \mathrm{X}$ increase to identify areas of increased microvascular density (hot spot) was performed. Once identified this area, proceeded to capture the image with an eyepiece lens and objective 10 X 20 X 40 and X, totaling an increase of 200 and $400 \mathrm{X}$. The photographs were used to reveal the distribution of cells and cells present in retail, were derived stem cells DiI-positive, previously transplanted.

\section{Results}

Obtaining the adipose tissue was found to be possible by removing 0.5 to $1.0 \mathrm{~g}$ of fat in each inguinal region of each animal, total 1.0 to $2.0 \mathrm{~g}$ per animal. Cells of the third passage were analyzed by immunotyping, and were positive for CD105, CD73 and CD90 antibodies and negative for CD45 (Figure 3).

Cells presented as adherent cell proliferation and differentiation capacity in vitro into osteoblasts, adipocytes and chondroblasts (Figure 4).

The image pickup by fluorescence microscopy with a 200 and $x 400$, showed the presence of multiple cells stained red fluorescent (DiI-positive) along the flap. The stained cells were predominantly located around blood vessels and capillaries (Figure 5).
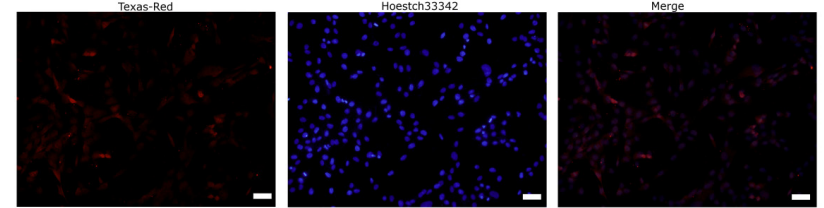

CD73
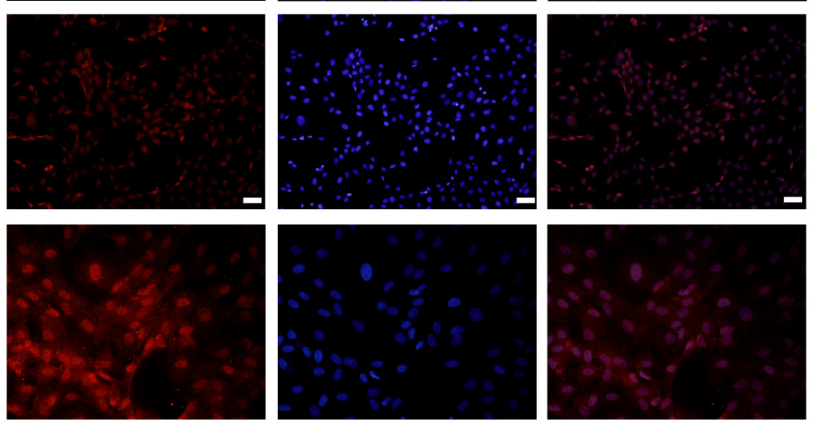

CD90

CD105

FIGURE 3 - Immunotyping for characterization of mesenchymal stem cells derived from adipose tissue. Positive for CD105, CD73 and CD90.

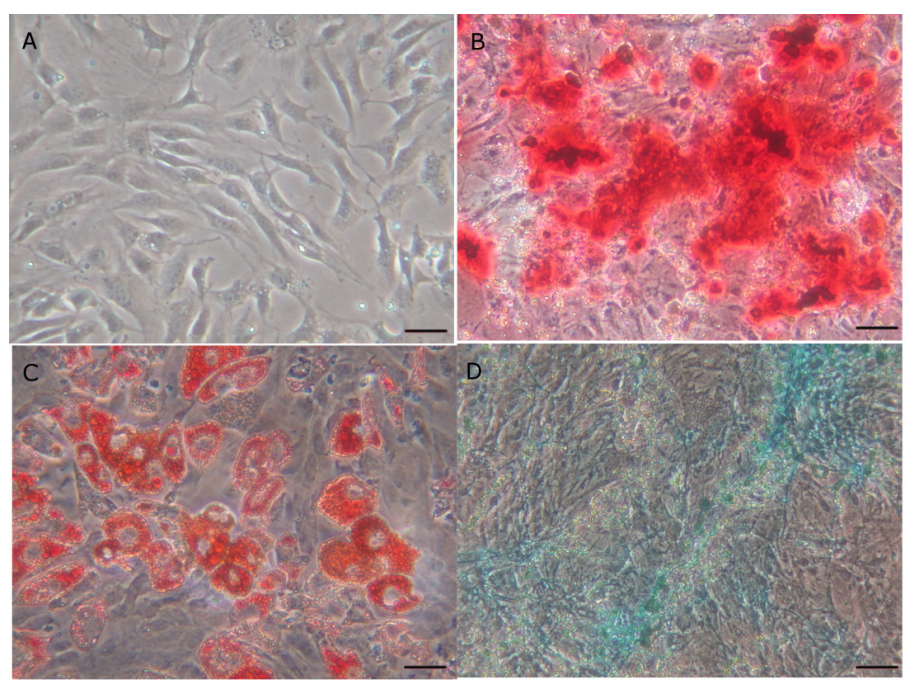

FIGURE 4 - Differentiation of Mesenchymal Stem Cells in three different cell types. A: Undifferentiated cells. B: Differentiation for osteocyte. C: Adipocyte differentiation for. D: Chondrocyte differentiation.

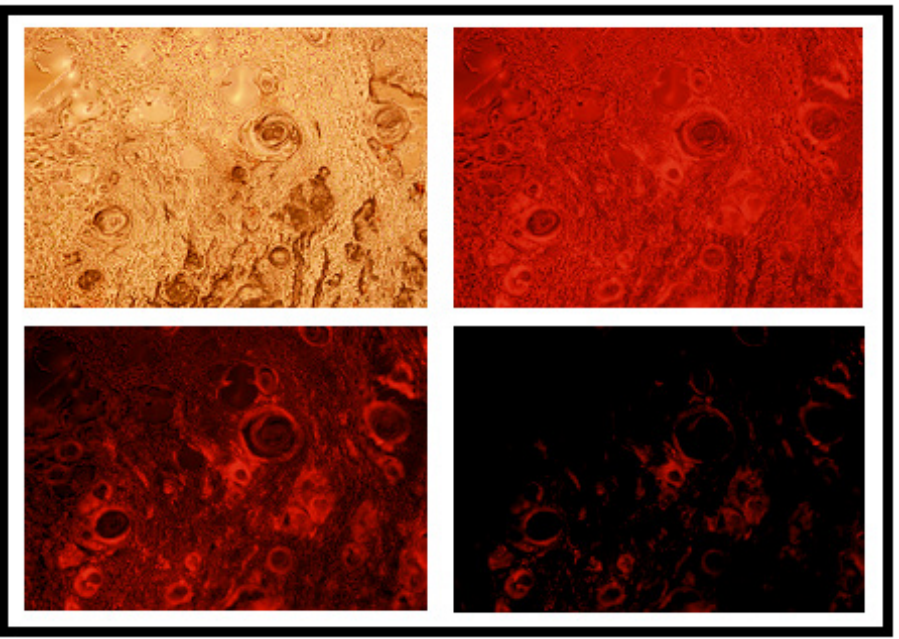

FIGURE 5 - Dil-positive cells, mesenchymal stem located with fluorescence microscopy. Blade with 400X magnification with gradual removal of light intensity, the same observation area, maintaining only the fluorescence. 


\section{Conclusion}

It was possible to establish an experimental model for obtaining adipose tissue for isolation of mouse mesenchymal stem cells and their distribution in the TRAM flap in rats.

\section{References}

1. Zuk PA, Zhu M, Mizuno H, Huang J, Futrell JW, Katz AJ, Benhaim P, Lorenz HP, Hedrick MH. Multilineage cells from human adipose tissue: Implications for cell-based therapies. Tissue Eng. 2001;7: 11.

2. Mizuno H, Zuk PA, Zhu M, Lorenz HP, Benhaim P, Hedrick MH. Myogenic differentiation by human pro-cessed lipoaspirate cells. Plast Reconstr Surg. 2002;109:199.

3. Zuk PA, Zhu M, Ashjian P, De Ugarte DA, Huang JI, Mizuno H, Alfonso ZC, Fraser JK, Benhaim P, Hedrick MH. Human adipose tissue is a source of multipotent stem cells. Mol Biol Cell. 2002;13:4279.

4. Asahara T, Masuda H, Takahashi T. Bone marrow origin of endothelial progenitor cells responsible for post-natal vasculogenesis in physiological and pathological neo-vascularization. Circ Res. 1999;85:221.

5. De Ugarte DA, Alfonso Z, Zuk PA. Differential expression of stem cell mobilization-associated molecules on multi-lineage cells from adipose tissue and bone marrow. Immunol Lett. 2003;31:267.

6. De Ugarte DA, Morizono K, Elbarbary A. Comparison of multilineage cells from human adipose tissue and bone marrow. Cells Tissues Organs. 2003;174:101.

7. Planat-Benard V, Silvestre JS, Cousin B. Plasticity of human adipose lineage cells toward endothelial cells: Physiological and therapeutic perspectives. Circulation. 2004;109:656.

8. Rehman J, Traktuev D, Li J. Secretion of angiogenic and antiapoptotic factors by human adipose stromal cells. Circulation. 2004;109:1292.

9. Lu F, Mizuno H, Uysal CA, Cai X, Ogawa R, Hyakusoku H. Improved viability of random pattern skin flaps through the use of adipose-derived stem cells. Plast Reconst Surg. 2008 Jan;121(1):50-8.

10. Dominici M, Blanc K Le, Mueller I, Slaper-Cortenbach I, Marini FC, Krause DS, Deans RJ, Keating A, Prockop DJ, Horwitz EM. Minimal criteria for defining multipotent mesenchymal stromal cells. Cytotherapy. 2006;8(4):315-7.

11. Dunn RM, Mancoll J. Flap models in the rat: a review and reappraisal. Plast Reconst Surg. 1992 Aug;90(2):319-27.

12. Dunn RM, Huff W, Mancoll J. The rat rectus abdominis myocutaneous flap: a true myocutaneous flap model. Ann Plast Surg. 1993 Oct;31(4):352-7.
13. Hallock GG, Rice DC. Evidence for the efficacy of TRAM flap delay in a rat model. Plast Reconst Surg. 1995 Nov;96(6):1351-7.

14. Ely PB, Miltersteiner AR, Hoff FC. Retalho miocutâneo transverso de músculo reto abdominal (TRAM flap) - modelo experimental em ratos. Acta Cir Bras. 1997;12 (Suppl 2):75.

15. Ely PB, Goldenberg S, d'Acampora AJ. Efeito da autonomização no retalho miocutâneo abdominal transverso de músculo reto abdominal - estudo experimental em ratos. Acta Cir Bras. 1999;14(2):25.

16. Hallock GG, Rice DC. Fate of the TRAM flap after abdominoplasty in a rat model. Plast Reconstr Surg. 1998 Jun;101(7):1828-35.

17. Ely PB, d-Acampora AJ, Miltersteiner AR, Hoff FC. Dispositivo do tipo colar cervical para proteção de ferida operatória abdominal em ratos. Acta Cir Bras. 1997;12 (Suppl 2):15-6.

18. Freitas ALP, Gomes HC, Lisboa BCG, Arias V, Han SW, Ferreira LM. Effect of Gene Therapy with Vascular Endothelial Growth Factor after Abdominoplasty on TRAM Flap Viability in a Rat Model. Plast Reconstr Surg. 2010 May;125(5):1343-51.

19. Lineaweaver WC, Lei M-P, Mustain W, Oswald TM, Cui D, Zhang F. Vascular endothelium growth factor, surgical delay, and skin flap survival. Ann Surg. 2004 Jun;239(6):866-73.

20. Asahara T, Murohara T, Sullivan A. Isolation of putative progenitor endothelial cells for angiogenesis. Science. 1997 Aug;275: 964.

21. Isner JM, Asahara T. Angiogenesis and vasculogenesis as therapeutic strategies for postnatal neovascularization. J Clin Invest. 1999 Aug; 103:1231

22. Kalka C, Masuda H, Takahashi T. Transplantation of ex vivo expanded endothelial progenitor cells for therapeutic neovascularization. Proc Natl Acad Sci USA. 2000 Aug;97:3422.

23. Tepper OM, Galiano RD, Kalka C, Gurtner GC. Endothelial progenitor cells: The promise of vascular stem cells for plastic surgery. Plast Reconstr Surg. 2003 Feb;111:846.

\section{Correspondence:}

André Luiz Pires de Freitas

Disciplina de Cirurgia Plástica-UNIFESP

Rua Napoleão de Barros, 715/4 andar

04024-002 São Paulo - SP Brasil

Tel.: (55 11)5576-4118

Fax: (55 11)5539-0824

sandra.dcir@epm.br

${ }^{1}$ Research performed at Plastic Surgery Division, Federal University of Sao Paulo (UNIFESP), Brazil. 